\title{
Evolutionary Changes in Thematic Lyrics in Songs with Reference to the Akamba Circumcision Songs in Kenya
}

\author{
Musembi N. Naomi \\ School of Education, Mount Kenya University \\ Email:omisembi@yahoo.com
}

\section{Doi:10.5901/mjss.2014.v5n5p}

\begin{abstract}
This study investigated changes of themes in Kamba circumcision songs with the aim of finding out the causes of these changes. The research was conducted at Nzyiitu, Kalimbui, Kaluilaa, Ngalange, Mwangea and Nzanzeni. The study was conducted in this area because the Kamba people living here still hold onto the practice of circumcision rites despite socialeconomic shifts in the ever changing society. The research was guided by the theory of ethnography of communication whose proponent is Dell Hymes. This theory emanates and inclines on sociolinguistics approach. Ethnography of communication is concerned with people's culture, situations, uses of language and its patterns and the functions of speaking. To arrive at the above stated aim, twenty four Kamba circumcision songs sung in different epochs in history were used as a yardstick of evaluation.
\end{abstract}

Keywords : Songs, Muisc, Educaion, Lyrics, Communication, Culture, Initiation

\section{Background}

Oral Literature is an important genre of literature in society in which responsible social culture is manifested (Omari 2008). The Kamba like other ethnic community, do have a culture which is expressed through oral literature in which they project their viewpoints. The various subsidiaries of oral literature they use are songs, stories, proverbs among others. To them oral literature comprises description of living trends, opinions, and the philosophy of life (Ndeti 1972). Oral literature provides a world view of the community from which the state of everyday life is expressed (Nyaga 1986).

Scholars agree that oral literature plays an important role in society. It contributes in developing, maintaining the history and culture of the community and builds up the realities of everyday life. According to Simiyu (2007) songs as the genre of oral literature continue to change as society develops anew social change. Oral literature of a particular community may be affected by changes as it occurs due to migration, interaction and social relations, ethnic, religious, political, or economic factors. This study discusses the thematic changes in Kamba songs so as to determine if these songs focus on performing tasks according to social change that has caused new songs to emerge. In addition this work intended to clarify the factors that brought about these changes.

According to Njogu and Chimera (1999), history of the song has the same date of oral literature so, as we mention oral literature we must think of the song Songs are an important aspect of the local culture as they are used to transfer it from one generation to the other. Songs are used to educate, warn, edify, focusing among other duties. Contributing about songs, Finnegan (1970), says that the songs are thoughts sung and influenced by people having special powers or ideas. These ideas can not be delivered to the audience in casual conversation for them to be understood, or for the intended purpose to take effect.

According to Gibbe (1978), Senkoro (1987), Msokile (1981), Mulokozi (1984), Ntarangwi (1990), Mlacha (1995) and Omari (2008), songs are inspired by the environment. Finnegan (1970) holds that the environment generates emotions and ideas for the artist's songs. It is noted that when songs are sung, the singer uses many techniques in achieving the delivery of his message to the target audience. These factors include tips, complaints, sounds, tone, stations, intonation, silence, speed and so on. Finnegan says that the structure of life in African societies, involves the use of traditional songs in several important functions.

In the traditional African society songs accompanied all walks of life. Key among these are; circumcision, weddings, mourning, digging, resting, feeding livestock, raising a son, comfort, and in almost every activity songs were used to convey certain messages based on those activities. These songs had unique content to fit a given occassion or function. Content and accompanying styles could change with time and draw a picture of history and social trends. As 
Finnegan (1970) discusses that the content of the songs change with time based on the events of the society.

Nandwa and Bukenya (1983) argued that any work of literature does not exist in vacuum but acquires its content from the community. As the standard of living in a society evolves, so is does oral literature.These changes are manifested in songs because it is one of the fields of oral literature that exists and in which life evolves. This logic is the shaping impulse of this research whose aim was to identify lyric changes in initiation songs among the Kamba community in view of thematic changes of life as it evolves.

\section{Theoretical Support}

This study was directed by the Ethnographic Details of Dell Hymes (1974). Ethnographic analysis of linguistic communication is centered on social context, culture, and environment of local communities to identify the language and its use. The centrality of social theory is language and therefore the research focus on the use of language as a communication medium and how this communication process is initiated. It emphasizes the use of language by the characters in their roles in the society. This theory also focuses on different social systems with the use of language to get the intended message.

Ethnographic theory examines how people of a particular community use language to perform their duties, including advising, encouraging, defamation, soothing, comforting, sarcastic misbehavior, describing various emotions, cultural preservation, communication and even entertainment. In considering this aspect of ethnographic communication, Savile-Troike (1982) explained the system of communication as described by Hymes $(1964,1974)$. With reference to the study of Hymes (1964), for a complete communication between two people to occur, it requires different components. Hymes (1964), who was investigating human behavior made clear grounds to explore humanity in its natural state. According to Hymes (1974) any language can only be understood in different social contexts. Likewise its application in communication is considered in a way that affects certain act or acts.

Through this approach, the study analysed songs among the Akamba people in consideration of all relevant factors in the genre of songs. This study chose this theory to analyze songs of the Kamba community because of the practices which are mysteries that can only be solved after assessing the language community with its environment. This theory contributed significantly to this research because apart from analyzing the type of language used in these songs, we were able to identify the meaning of words used in order to clarify the content of the songs of the Kamba community .This theory binds the audience, context and text.

\section{Literature on Lyrics}

Finnegan (1970) is one of the first experts who have done extensive research in the genre of African oral literature by focusing on the genre of songs. Finnegan has shown how the songs are used in everyday life and demonstrated how the songs have served to defend the rights of workers who find themselves in situations of violence especially in former colonies. He has pointed out that songs can be used as a tool for self-defence. African writers have written and researched on genre of songs. Nandwa and Bukenya (1983) are of the opinion that contemporary songs fit to contemporary issues but have characteristics of oral literature. Singers have great creativity of words and language they use. Kingei and Kisovi (2005) believe that modern songs are characterized by creative techniques that follow the modern style. Accordingly, these songs have modern contemporary content and use style of dance as well as modern instruments like guitar, piano and drums among others.

Mbiti (1993) says that songs, proverbs, fables and stories are available in many African societies. These tend to occur in a specified period and have a distinct message. In addition, they have specific content about certain aspects of life. Emphasis on the importance of songs in the community has further been articulated by Njogu and Chimera (1999) when they argued that songs and poems were used to preserve the law, history, geography, sociology and factors affecting all human disciplines to be passed from one generation to the next. According to Njogu and Chimera (1999), key issues such as murder, scandals, marriage, and sexual issues were preserved in songs.

According to Wamitila (2003) and Ngure (2007), songs have laden assumptions and reflect social relations. Songs are a great part of human life. Wamitila (2003) says that almost all activities of human life as cultivating, developing and harvesting are accompanied by songs. Similarly, Wamitila (2003) explained the concept of songs and clarified its role as a genre of oral literature in society. King'ei and Kisovi (2005),discuss that songs have spread among various communities and are performed in accordance with various activities 


\section{History of the Origin of the Kamba Community}

According to Senkoro (1987), in order to understand the literature of any community, one must understand its history. He gives grounds upon which to explore the history of the Kamba community so as to understand their songs and how they change according to social change. Kamba community is one of the larger Bantu groups (King'ei 1982). The Kamba people have one language which is their key instrument of cultural and literary expression.

According to Kavyu (1980), the Kamba community is described by various theories. One of them explains that the AKamba people moved to the mountains of Chulu and Mbooni from Mount Kilimanjaro between 1450 and 1550. Due to the increase in population and other problems like drought and the invasion of the Maasai community, the Kamba people moved to other parts of the counties of Machakos and Kitui.

Another theory about the origin of the Kamba is through their oral literature. According to (Kimilu 1962) AKamba people came up from the mountain ' Ngai ' then they settled in the counties of Machakos and Kitui. Based on this original story, the Kamba community emerged when the two brothers who were married and got children who multiplied and became familiar with the different genealogies (Kimilu 1962).

According to King'ei (1982), age, marital status and integrity are the criteria used to appoint leaders. Kamba men began to take roles in the society after circumcision. When young people went through ceremonies, they were called warriors. This group was given responsibility to protect the Kamba community. Before them, was another group known as "Nthele" who took leadership roles. Nthele is a man who has undergone a circumcision ceremony or gone through circumcision rites, married and has children. Kamba community had no caste order. People lived in social groups and family depended on each other.

Culturally, they have deep rooted customs practiced for example during marriage and initiation. Just like in many Kenyan tribes, during marriage their dowry is usually paid in form of goats and cows with a recent acceptance of money. Something interesting about the Kamba is their value for ceremonies and parties. As a result, unlike the one-day events popular in the West, the Kamba weddings go on for an extended phase of about two weeks (http:// www.enhols.com/kenya_safari/people/akamba/).

Child Naming is a significant facet of the Akamba culture. Children are often lovingly called names like Musumbi which means (the "king"), and Muthoki/Nthoki (which means"long awaited one"). In most cases, children are named for/after time or events surrounding their birth. For instance, Nduku is given to a baby girl born at night and Mutuku to a baby boy born at night. They believe in a monotheistic, invisible and transcendental God Ngai, who resides up in the sky ('yayaani'). Initiation into maturity was demonstrated with circumcision, for males and many females as well but after female circumcision got officially banned in Kenya; many have decided to abandon it (http:// www.enhols.com/kenya_safari/people/akamba/).

\section{Circumcision}

Circumcision was and is still very important for community members who practice it. The purpose of this practice is to circumcise and educate about many things, especially secret society, customs and traditions, roles in conjugal affairs, history, society and ideas on manhood. Ceremonies were conducted by their supervisors. These ceremonies according to Kavyu (1980) were made during the summer between eighth and ninth month and lasted between six and ten days. Young people married after getting permission through a large circumcision ceremony. Songs performed during circumcision had the purpose of educating the initiates about marriage and other functions. Specific songs were sung every day that were in the context of this community. Circumcision was made after a great practice in which the-would be initiates were sent to be trained in guerrilla tactics in order to defend the community. The following song was sung during circumcission:

\begin{tabular}{|l|l|}
\hline Song in Kikamba & Translation \\
\hline Mwaikwa ndaneenaa and kiveti kyeene & The circumcised does not talk to another man's wife \\
Mwaikwa ndaneenaa and kiveti kyeene & The circumcised does not talk to another man's wife \\
Mwaikwa kusya mbusya tuthi, Vate kukia & The circumcised should pull the rhino \\
Ula unuukia & Without fear \\
Ula waikitwe ndaneenaa and kiveti kyeene & The circumcised does not talk to another man's wife \\
\hline
\end{tabular}

This song was sung on the last day before going home from the forest. The purpose of this song was to advise on matters of sex. The initiates were warned against speaking to the ladies to whom they related by blood. This was 
because the community upheld morals of society and the initiates were to honour women. Circumcision is a rite of passage that is highly respected among the communities that practice it (Mwaniki 1986). Mwaniki explains that given the importance of this ritual, the youth expressed a great desire to go through it as soon as they became of age. This is a fundamental ritual in traditional Kamba community and every member of the community waits for it eagerly. The central role of circumcsion songs in the Kamba community was to educate young people about the expected daily life in the society (Kimilu 1962). Initiates were taught much about courage, perseverance in life, hard work, social integration, issues of sex, secrets of the society, marriage issues among other training.

Similarly, circumcision was a sign of uniting the initiates who then formed an ageset. Circumcision was important across the Kamba community and was a conduit for the entire community in which everyone was required to attend. Both young and old were required to take part especially in the singing which brought people together and maintained their unity. It also improved the community's sense of identity as well as being a physical therapy for psychological problems faced by those who sung (Nzioki, 1982).

\section{Content of Songs}

Ndungo (1985) says literature is a reflection of the realities of life in which artists or the community member writes to tell from the experience that he/she gets from the society. Ngugi (1993) says literature does not come from vacuum but receives direction, shape and its importance from emerging issues in specific communities. According to Ngugi ( ibid ), content sources in oral literature include economics, politics, education, religion and any changes that happen in any sphere of social life. Changes in life spheres affect the work of literary content. Ngugi (1993) further explains that the main events of a decade can be identified from the literature of the decade through the elements of content. His comments are shared by Njogu and Chimera (1999) who hold the opinion that, literature is exists and changes as the society continues to change. The study found that some of the content of traditional songs has changed to some degree. There have been changes that are caused by the Christian religion, education, white systems of production, politics, and health among other changes in society. Change in the content of the songs according to experts like Kingei and Kisovi (2005) is because the song is a genre of oral literature which develops, grows and is flexible due to the transition of time and changes in the social structure. These changes arise from the need, time and the environment.

\section{Content from Period of Years 1960-1999 To 2000-2013}

The aim of this study was to examine whether the content of the songs in the Kamba community has changed according to social change. After comparing content of these songs in two periods of study chosen, the content seemed to change. The first period of the study indicates the following content: rivalry, courage, cooperation and social interaction, adult, community history, killing relationships among other content.

Moral content can be found in the songs of two periods. According to the findings, moral content is very basic in songs. In this changing the Akamba society has witnessed significant changes in the behavior of young people. Teenagers rebel against traditional social values. Young people are tied to crimes like theft, rape, drug use, and violence (Kaui, 2008). Songs within the two periods of study have empasized moral content to rehabilitate young people and society in general due to immoral behavior in the society.

Ethical content is governed by ideology and social customs of the Kamba in songs sung before the entrance of the colonists. Communities were believed to follow if they considered moral traditions and cultures as having good social integration, focus on the tasks set by the community, show respect for superiors, be diligent, among others. With regard to circumcission, the role of songs is to educate about basic morals. Young people are encouraged to follow the traditions and cultures of the Kamba when choosing a wife. Also in the second period, community members are warned against HIV infection. These songs have a moral advice like to have one partner to avoid contracting the disease.

The importance of cooperation during important social ceremonies like circumcision has been encouraged through songs where each community member is required to attend this ceremony to show social cohesion. According to the Kamba community, ceremonies were for all members of society as they belong together and signaled a kind of social relationship .In ceremonies, songs passed down a message to all. Cooperation in the second period is referred to in connection with the community politicians who are required to cooperate in order to win the leadership roles they expect.

The importance of songs including their use to spark historical events has taken place in this area. Lyrics that contain history are important for generations of Kamba and non Kamba. As Simiyu (2007) points out, oral literature, including songs show destruction to changes in life caused by modern education and the Christian religion that put in consideration modern hospital and defamation of nature. 
The content of the history of the communityis spelled through songs where the circumcised are told that Kamba predicted the advent of the whites who would bring new knowledge and new languages. This is a key milestone for the modern generation Kamba which has been preserved in the modern song for future generations. In the opinion of the researcher, Oral literature,is threatened to be ruined through social changes brought about by new educational institutions like Western education, Christian religion, new methods of production, science and technology, among others. Since the world has changed so has literature, including the genre of songs that changed to correspond to social change, circumcision songs should be studied further and stored so that they are a reminder of the traditions and cultures of the community in the near future.

Similarly, the content of stereotyping women was reflected in the first period of the study. Here a Woman was presented as prostitute, who does not use logic in having sex with young men who are not circumcised, as the property of every man, as products that are sold, and whose place is in the kitchen. There is content that is available in the first period of the study but not in the second period of the study, especially the content about courage during circumcision.

Also, the circumcised are educated about the difficulties of first sex after circumcision. This content is projected in modern songs. The content of having confidence is seriously focused on in the second half of the study because in the previous study, a circumcised man was to show the courage to reveal that he was ready take responsibilities as a married man and provide for his family. Similarly, the circumcised were expected to show resilience in responding to a circumciser's knife ready to declare that he can take the social responsibility to protect the society from any invasion. Nowadays, the role of social protection is no longer there it has been delegated to security officials. In addition, the importance of the circumcised's courage to reveal that he was ready to marry and support his community does not exist because people are circumcised at younger ages, especially 9-12 years (Wahome, 2009). After circumcision, communities do not expect them to marry but continue to study in order to get a good job and contribute to their community. New content that is not in the songs of the first period and that shows social change shows how the Akamba people are living and may vary according to social change. Precautions related to HIVIAIDS infections.

In addition, content about God as head of the Christians (Faith in Christian religion) and has a role in the lives of community members have been identified clearly in some of the songs in the second half. Initially, this study dealt with the religious aspect of the Akamba people before and after the advent of the colonialists. The study noted that, the Kamba community before the coming of the colonial government was religious. ( Mbiti 1969 ). The Kamba believed in the existence of God who was powerful through the symbolic names that he was given in reference to his abilities especially Mulungu ( God ), Mumbi ( Creator ), Mwatuangi ( who separated fingers),and Ngai ( distributing ).

According to Mbiti (1969), Kamba community gave God a bigger role in their daily life. Before implementing any eating and drinking for example, drinks and a little food was poured down on the groundand blessed the participants. Before planting, agricultural equipment was presented before God and a sacrifice made to God to bless their work. After harvesting some crops were placed in a popular place known as ithembo and released to the gods. Before going to war, the Kamba took part in prayers to pray for victory in battle. Important social ceremonies particularly childbirth, circumcision, weddings, funerals among others were not perfomed before sacrifice. After the advent of the colonialists, the Kamba were hurriedly pushed into Christian religion and through it, some modern songs that potray their faith in the power of God in their lives have emerged.

Change as the content also presented in contemporary songs which concentrated on importance of Western education. Songs underline the importance of new knowledge that changes the lives of young people and saves them from physical work such as digging some famous canals. The work of digging trenches has very limited income even though it is difficult. This song for the circumcised and the young encourages them to study and change their lives through education.

Sexual content found in modern songs has been caused by social changes which in today's world, young people are seeking partners unlike in the traditional Kamba society where his parents of the uncles would be involved in choosing of a marriage partner. King'ei (1982) argues that the Kamba marriage was established by the parents after the girl's behavior was researched on accordingly. The boy's parents got a girl. From a family which was known to be good and not of witches. Because today's youth are rebelling this tradition, and have begun seeking women in urban areas and from different tribes, these songs warn teenagers about sex for money. Those with money get lovers who are good but those without money get women of low class. Issues of discussing sex in public which was not tradition emerged in this category. After the coming of the colonists, songs changed their content to focus on money economy. This is a change from the first period to the second where the economy was based on cattle, goats, sheep, donkeys and products from the field. After the entrance of the colonists, the economy relied on money which also determined romantic relationships.

Similarly, showing the importance of being contenteded with one's partner can be found in modern songs but was not in the first period of the study. Initially in the first period of the study, the circumcised were sang for songs that 
explained that women are like farms and anyone can grow on them in the sense that any man can have sex with them. This content has changed in the second period of the study. At present community members are educated about the importance of having one woman as life changes and incurable diseases like AIDS are emerging.

Importance of cooperation as content in his songs is spelled from the first period to the second covered in this study. Kamba community has continued to focus on political issues in their oral literature. Some of the songs sung at the ceremony show importance of social integration even at the political level. Politicians are advised to have a partnership in order to succeed in politics. Modern songs are created to educate communities on the importance of unity and cooperation. Preliminary research suggests that, Kamba communities lived together under a family where every member of the community had to help a fellow clan member. It was not a caste system as the community lived communaly and everyone lived because another did Mbiti (1969).

Lyrics that focus on the content show importance of partnership to change political life. It is a sensitive issue which has emerged in modern life where the organization has experienced a turbulent marriage as marital breakdown, violence between the couple, killing, among others. These are changes to the content in the songs of which indicates that these songs change as the society changes.

In addition, modern criticism for teens being taken to hospital to be circumcised is an issue that shows the thematic changes in modern songs. Some members of the community, evident in the research $p$ take their children to hospital. Circumcision, according to them in the traditional way may be outdated and likely to expose those circumcised to contract AIDS through a circumciser's knife who do not understand the purity of their devices. Also, according to community members who take their children to the hospital, circumcision is not painful. In addition, their views of ignoring the tradition is that the world has changed and so is the society.

\section{Conclusion}

The study addresses thematic changes in the Kamba circumcision songs. Written in natural language to interpret the Kamba and then Swahili. Considering ethnographic communication theory, we have noted that some of the content of these songs have changed according to social change. As the standard of living continues changing e.g. technological, economic, political and nearly all aspects, oral literature, especially the circumcision songs have taken a new thematic direction. This is because the songs are a reality and reflects what life is about in the community. Among the Akamba people, culture continues to change. This is largely attributed to changes in educational, economic, religious, western culture, science and technology among other changes. The study reviews these songs in detail and proves that some of the content has changed according to emerging issues in the community. In addition, songs in this category continue to play important roles in society.

\section{References}

Austin, J. L. (1962). How to do things with Words. London: Oxford University Press.

Akivaga,S.K. ( 1982).Oral Literature: A school Certificate Course. Nairobi, East African Educational Publishers.

Bowman,W.D. (1998). Philosophical Perspective on Music. London. Oxford University Press.

Brake, M. (1980). The Society of Youth Culture and Youth Subcultures: Sex, Drugs and Rock ' $n$ ' Roll? London: Routledge and Kegan Paul.

Chacha, M.C. ( 1997). "Majigambo ya Kikuria. Mtazamo wa kiisimu". Tasnifu ya uzamili. Chuo Kikuu Cha Kenyatta. Haijachapishwa.

Chesaina, C. (1991). Oral Literature of the Kalenjin. Nairobi: Printing Industries.

Finnegan, R. (1970). Oral literature in Africa. London: Oxford University.

Finnegan, R. (1977). Oral Traditions and Verbal Arts; Guide to Research. London: Routledge.

Gibbe, A.G. ( 1978). Dhima ya mhakiki. MULIKA nambari 12 TUKI. Dar es salaam. Uk 18.

Hymes, D. (1964). Language in Culture and Society. Harper and Row, New York.

Hymes, D. (1974). Foundations in Social Linguistics: an ethnographic approach. University of Pennsylvania Press, Philadelphia.

Indangasi, H. (1997). "Gender Socialisation in the Maragoli circumcision Ceremony".

Katika W. Kabira. M, Masinjila and M. Obote (Wah) Contesting social death: Essays on Gender and Culture. Nairobi: Kenya Oral Literature Association. Uk 16-22.

Kabira, W. na Mutahi, H. (1988). African Oral Literature. Nairobi, Longman Kenya Ltd.

Kaplan, E.A. (1987). Rocking Around the Clock: Music, Television. Postmodernism and consumer culture. London: Mathuen.

Kavyu, P.N (1980). Traditional Musical Instument of Kenya. Kenya Literature Bureau, Nairobi.

Karanja, W. (2008). "Maswala ibuka katika fasihi ya watoto". Tasnifu ya M.A. Chuo Kikuu Cha Kenyatta. Haijachapishwa.

Kanake, A.K. (2001). "Change and continuity in the practice of Clitoridectomy: A case study of Tharaka of Meru East". M.A Thesis, Kenyatta University. Unpublished. 
Kaui, M. (2008). "Usawiri wa vijana Katika Tamthilia Teule za Kiswahili". Tasnifu ya M.A. Chuo Kikuu Cha Kenyatta. Haijachapishwa.

Kieti, M. ( 1999). "Myali songs. Social Critique among the Kamba" M.A. Thesis. Nairobi University.

Kieti, M. na Coughlin, P. (1990). Barking, U Will Be Eaten! The Wisdom of Kamba Oral Literature, Nairobi Phoenix.

Kilauni, N.M. (2007). "Usasa Katika Nyimbo ya Itheke". Tasnifu ya M.A, Chuo Kikuu Cha Kenyatta. Haijachapishwa.

Kimilu, D. (1962). Mukamba wa w'o. Nairobi East Africa Literature Bureau.

King'ei, K. (1982). "Uhakiki wa 'Nthimo' ( methali) za Kikamba kwa kufuatisha misingi ya methali za Kiswahili”.Nairobi. Haijachapishwa.

King'ei, K. (1992). "Language, culture, and communication. The role of Swahili Taarab Songs in Kenya 1993-1990". U.M.I. Dissertation information of Bells Howen Information company of Michigan U.S.A.

King'ei, K. na Kisovi, C. (2005). Msingi Wa Fasihi Simulizi. Nairobi. Kenya Literature Bureau.

Kinoti, M. (2008). Fasihi Simulizi na Utamaduni. Nairobi. JKF.

Kirumbi, P. (1975). Misingi ya Fasihi Simulizi. Nairobi: Shungwaya Publishers.

Kobia, M. ( 2008a). "Metaphors on HIVIAIDS Discourse Among Oluluyia Speakers of Western Kenya". In Critical Approaches to Discourse Analysis Across Displines. http://caddad.org/ejournal. Vol 2:48-66.

Kobia, M. (2008b). "Taswira za kiuana katika nyimbo za Tohara za wanaume miongoni mwa Waigembe". Tasnifu ya uzamifu. Chuo Kikuu cha Kenyatta.

Kobia, M. ( 2008c). "Nadharia ya utendaji katika uhakiki wa Fasihi ya Kiafrika: Nyimbo za tohara za Waigembe wa Meru Kaskazini". Katika Ogechi, Shitemi, Shimala (Whr) Nadharia katika taaluma ya Kiswahili na lugha za Kiafrika. Moi University Press, Moi University Eldoret. Uk 293-306.

Maitaria, J. ( 1991). "Methali kama chombo cha mawasiliano: mtazamo wa kiisimu-jamii", M.A Thesis, Kenyatta University.

Malenya,M.( 2008). "Matumizi ya jazanda katika nyimbo za Jacob Luseno". Tasnifu ya M.A Chuo kikuu cha Kenyatta. Haijachapishwa.

Matteru, L. B. (1981). Fasihi Simulizi na Uandishi. Makala y semina ya waandishi wa Kiswahili. Dar el salaam: TUKI.

Matti, G.N. ( 1996). "Sanaa za maonyesho za Kiafrika za jadi: Mfano wa Tohara ya Watharaka" M. Phil, Moi University. (Haijachapishwa).

Mbaabu, I. (1985). Utamaduni Wa Waswahili. Kenya Publishing and Book Marketing, C

Mbarwa, H. (1989) Your Oral Literature. Nairobi: Kijabe Printing Press.

Mbiti, J.S (1993). Love and Marriage. London. Longmans.

Mbiti, J.S. ( 1969). African Religion and Philosophy. East African Educational Publishers. Nairobi.

Mbogo,S. ( 2008). "Mabadiliko ya Maudhui Kiwakati katika Nyimbo za Harusi za jamii ya Waembu".Tasnifu ya M.A. Chuo Kikuu cha Kenyatta. Haijachapishwa.

Mkimbo, M. (1981). "Song as a political weapon during 1974/75 General Elections in Lamu" Unpublished M.A Thesis, Nairobi: University of Nairobi.

Msokile, M. (1993) Misingi ya Uhakiki Wa Fasihi. East African Publishers: Nairobi.

Momanyi, C. (1998). "Usawiri wa Mwanamke Mwislamu katika jamii ya Waswahili kama inavyobainika katika ushairi wa Kiswahili", Tasnifu ya Ph.D Chuo kikuu cha Kenyatta. Hijachapishwa.

Momanyi, C. (2001). "Nafasi ya mwanamke katika ushairi wa Shaaban Robert", Katika Kiswahili juzuu 64. Dar es Salaam: TUKI.

Mugenda, O na Mugenda A. (1999). Research Methods. Quantitative approaches and qualitative approaches. Nairobi: Acts Press.

Mulokozi,M. (1984). "Nafasi ya nyimbo za fasihi simulizi katika jamhuri Inayobadilika". Makala yaliyowasilishwa katika semina ya fasihi simulizi. Jarida la Taasisi ya Uchunguzi wa Kiswahili. Dar-el-Salaam. Uk 21-33.

Mulokozi, M.M. (2003). "Utafiti wa fasihi simulizi, katika makala ya semina ya Kimataifa ya waandishi wa Kiswahili". TUKI. Dar es Salaam. Uk 18-26.

Mutwiri, G. (2005). "Mitazamo ya utendakazi wa nyiso katika jamii ya Watigania". Tasnifu ya uzamili, Chuo Kikuu Cha Kenyatta. Haijachapishwa.

Mvumbi, F.N. ( 2008). Journey into Islam.Paulins Publications Africa, Nairobi.

Mwai, K.W. (1997). "The Power of Song for Swahili Woman. Contesting social Death". Tasnifu ya M.A Chuo kikuu cha Kenyatta. Haijachapishwa.

Mwaniki, H. (1986). Categories and Substance of Embu Traditional Songs and Dance. Nairobi: Kenya literature Bureau.

Mwamzandi ,Y. na Nkichabe, S. (2008). Udenguzi wa maana katika diskosi ya kisiasa nchini Kenya: Mifano ya nyimbo pendwa. Katika Ogechi, Shitemi, Simala. (Whr.) Nadharia katika Taaluma ya Kiswahili na lugha za Kiafrika. Moi University Press, Moi University Eldoret. Uk 307-317.

Nandwa, J. \& Bukenya, A. (1983) African Oral Literature for schools Nairobi: Longman.

Nandwa,J. (1976). "Oral Literature Among the Wabaluyia" M.A Thesis, Nairobi University.

Nang'oli, M. (2000). No more lies About Africa. New Jersey: African Heritage Publishers.

Ndeti, K. (1972). Elements of Akamba Life, EAPH.

Ndungo, C. (1985). "Wanawake na Mabadiliko ya Kihistoria Katika Fasihi ya Kiswahili." Tasnifu ya M.A Chuo Kikuu Cha Kenyatta. Haijachapishwa.

Ngugi Wa Thiongo, ( 1993). Moving the centre. The Struggle for Cultural Freedoms. London, James Currey.

Ngure, A. (2007). Fasihi Simulizi Kwa Shule Za Sekondari. Nairobi: Phoenix Publishers Limited.

Njiru, E. (1981). "Indigenous Education as Practiced By the Ameru with Reference to Circumcision Ceremonies". Tasnifu ya M.A. Haijachapishwa.

Njogu, K na Chimerah, R. (1999). Ufundishaji wa fasihi. Nadharia na Mbinu. Nairobi. Jomo Kenyatta Foundation. 
Njogu, S.K. (1987). "Maudhui ya Mapinduzi katika Riwaya Za Visiwani”. Tasnifu ya M.A. Chuo Kikuu Cha Nairobi. Imechapishwa. Nketia, J.K. (1974). The Music of Africa. New York:Norton and Co. Inc.

Nkonge, M. (1988). "Literary Study of Songs of Joseph Kamaru. Theme and Style' Tasnifu ya M.A. Chuo Kikuu cha Kenyatta Haijachapishwa.

Ntarangwi, G.M. (1990). "Uhakiki wa maudhui ya utetezi katika utunzi wa Remmy Ongala". Tasnifu ya M.A. Chuo Kikuu Cha Kenyatta. Hajachapishwa.

Nyaga,D. (1986). Mikarire na Miturire ya Amiiru. Nteto cia Bajuju Betu. Nairobi, EAEP.

Nzioki, S (1982). People of Kenya. The Akamba. Evans Brothers.

Obote, M. (1997). "The Role of Song in the Ideological and Social Construction of Gender. Power relations in Karachuonyo". In W. Kabira, M. Masanjila and M.Obote (Whr.) Contesting Social Death. Essays on Gender and culture. Nairobi Kenya. Oral Literature Association. Uk.67-79.

Odaga, A. (1985). Literature for children and Young people in Kenya. Nairobi: Kenya Literature Bureau. PhD Thesis, School of English, Univertsity of Leeds. Unpublished.

Okombo, M. (1998). Encounter with oral Literature. Nairobi: E.A.E.P.

Okumba, M. (2001). Oral Literature of the Luo of Kenya. Nairobi, East African Educational Publishers.

Olali,T. (2004) "The Veneration of the Prophet: The Role of Kasida ya Hamziyya during the Maulidi Festival of Lamu Archipelago, Kenya". Tasifu ya Uzamifu, School of Oriental and African Studies. Chuo Kikuu cha London. Imechapishwa.

Omari, S. (2008). "Fasihi Simulizi na jinsia. Mifano kutoka nyimbo za watoto Tanzania". Katika Massamba (Mhr). Jarida la Taasisi ya uchunguzi wa Kiswahili. Chuo Kikuu cha Dar es Salaam.Uk 98-106.

Rimitta,D. (1988). The Njuri Njeke of Meru. Nairobi, Koble Press.

Saville-Troike, ( 1982). The Ethnography of Communication. An Introduction. London, Blackwell Publishers.

Senkoro, F.K.M.K. (1987). Fasihi na jamii. Dar es salaam. Presss and Publicity Centre.

Simiyu, F.W. (2007). ' Nyiso za Wabukusu. Maudhui na Lugha”. Tasnifu ya M.A. Chuo Kikuu Cha Kenyatta. Haijachapishwa.

Singleton, R.A. (1993). Approaches to social research. New York: Oxford University Press.

Somba, J.N. ( 1972). Elements of Kamba Life. Nairobi, E.A.E.P.

Somba, J.N. (2000). Ndeto Sya Thome. Kagundo : Somba Publications.

United Nations (2005). World Youth Report.http:/www.Un.org/esa/soccer/Unyin/index.htm/

Wambua, S. (2001). "Mtindo na matumizi ya Lugha katika nyimbo za Kakai Kilonzo". Tasnifu ya M.A. Chuo Kikuu Cha Kenyatta. Haijachapishwa.

Wamitila, K. (2002). Uhakiki wa Fasihi, Misingi na vipengele Vyake. Nairobi: Phoenix Publishers.

Wamitila, K. (2003). Kichocheo cha Fasihi Simulizi na Andishi. Nairobi. Focus Books.

Wanyama, M.N. (2005). "Ujumi katika muziki wa Kiafrika : Mfano wa muziki wa tohara ya Wambukusu". Tasnifu ya Uzamili, Eldoret: Chuo Kikuu Cha Moi..

Wathome, R. (2009). "Mtindo Katika Nyimbo za jamii ya Wakamba wa Masaku ya Kati". Tasnifu ya Chuo Kikuu Cha Kenyatta. Haijachapishwa.

Watuma, B. ( 2001). Mukamba na Syithio syake. Nairobi. Sengani Publishers.

Yalwala, P. (1991). "Maudhui katika nyimbo za John Mwale". Tasnifu ya M. A. Chuo Kikuu cha Nairobi. Haijachapishwa. 